\title{
Assessing the quality of collaboration towards the achievement of Sustainable Energy Innovation in PFI school projects
}

\section{Introduction}

The ability of the Private Finance Initiative (PFI) and Public-Private Partnerships (PPPs) project delivery models to foster innovation has always been an important raison d'etre for the procurement strategies (HM Treasury, 2003). Private sector involvement in public service provision is seen to stimulate innovative capacity and maximise financial returns over the whole-life cycle of the project (Roumboutsos and Saussier, 2014). The prevailing view is that PFI provides real incentives to innovate by putting in place unique cooperative arrangements between clients, designers, constructors, and operators. These cooperative arrangements in combination with added incentives and long-term commitments will ultimately encourage innovative solutions to the public sector client's requirements (Russell et al., 2006). Indeed, Leiringer (2006) argues that PPP/PFI project delivery models are somewhat envisaged as a 'vehicle for change' and a panacea for the construction industry.

The innovation capacity of PFI is nowhere more needed than in meeting global pressures for sustainable energy and $\mathrm{CO}_{2}$ reduction. Several studies have underlined the importance of collaborative inter-organisational networks and partnerships in contributing to the development of environmental policy and management (Roome, 2001; Malmborg, 2007; Valkering et al., 
2013). Malmborg (2007) proposes that collaboration in public-private partnerships should actively foster the capacity for knowledge creation, discovery and innovation required for sustainable development. In fact, the concepts of improved inter-organisational collaboration and sustainability have been prominent in construction improvement initiatives (DETR, 2000; Egan, 1998; Latham, 1994) and a central theoretical paradigm influencing general and industry-specific research studies of sustainable development (De Bruijn and Tukker, 2002; Frantzeskaki et al., 2014).

In the construction industry context, several scholars have also highlighted the importance of inter-organisational relationships for innovation (e.g. Eriksson and Westerberg, 2010; Dewick and Miozzo, 2004; Nam and Tatum, 1988). Early work by Nam and Tatum (1988) underlined the need for long-term relationships between organisations in the construction industry to promote innovation. Manseau and Seaden, (2001) argued that policies promoting cooperative arrangements between organisations are effective innovation drivers. Dewick and Miozzo (2004), and Dorée and Holmen (2004) similarly point out the essential role of strong interorganisational relationships for technological innovation in construction projects.

The study presented here sought to provide new knowledge on the management of collaboration in innovation processes by empirically examining the quality of collaboration towards Sustainable Energy Innovation (SEI) in PFI procurement. The focus of the study was on SEIs, which are defined as novel technological products and solutions that are successfully integrated into a building's design strategies to either increase energy efficiency or utilise renewable energy generation. Several government and policy reports have underlined the importance of technological innovation as a dominant strategy for the smooth reduction in greenhouse gases emissions (DEFRA, 2007; DTI, 2007; Stern, 2006). The Stern Review on 
the Economics of Climate Change stressed the need for innovation and discovery (Stern, 2006). It emphasised that "policy to support innovation and the deployment of low carbon technologies will be a key response to mitigating Climate Change' (DTI 2007: 216). However, others have acknowledged that such innovations are still in their 'embryonic' stages (e.g. Bulkeley et al. 2013; Kelly, 2008). Rennings (1998: 2) calls for further research in order to improve our understanding of innovation processes towards sustainability in their different dimensions, complex feedback mechanisms and interrelations'.

In order to empirically examine the quality of collaboration towards SEI in PFI procurement, this study adopts a conceptual model in which the PFI project is conceptualised as a Complex Product System (CoPS). In this model, innovation success is seen to largely depend on effective collaboration at the interfaces of the super and infra-structure levels of the system (Hobday, 1998; Hobday et al., 2000). Particularly, the study examines the relationship between the innovation superstructure of public sector clients and users, and the innovation infrastructure of private sector designers, contractors and operators. It also considers the role of the "System Integrator", managing the interface between the two structures, in aligning project objectives and creating a collaborative environment conducive to SEI. In this paper, following Dietrich et al., (2010: 63), we assess the quality of collaboration in PFI projects in terms of the 'fluency of interactional activities taking place between the collaborative actors'. Two interactional elements are examined upon which the project-collaboration quality is assessed: (i) effectiveness of communication and (ii) alignment of objectives. We apply the model to four new-build PFI school projects within the context of the UK government Building Schools for the Future (BSF) Programme. By doing so, the study may lead to a greater awareness of how complex public procurement should work to encourage more innovative activity in the 
construction industry and to the growth or even creation of markets for innovative sustainable products and services.

The study will contribute to the extant literature on the management of innovation by addressing the lack of studies on managing CoPS sustainable innovation processes as well as the limited attention to procurement issues in the CoPS literature. In addition, there is a paucity of empirical research into innovation in PFI procurement models and the works of Eaton et al. (2006), Barlow and Köberle-Gaiser (2008), and Leiringer (2006) are among the few that can be identified. No empirical research has examined the capacity of PFI project models to stimulate innovation for sustainability, including SEI. This represents a theoretical and empirical gap in knowledge because innovation for sustainable energy is a global phenomenon that requires sufficient consideration of the dynamics that encourages its development and success.

The remainder of this paper is structured as follows: first, we define SEI and explore the main theoretical lenses pertaining to environmental innovation management. We then introduce the PFI project delivery model and describe the conceptual approach adopted in order to examine the quality of collaboration towards SEI in PFI projects. The conceptual approach adopted is then discussed using findings from four case studies of new-build PFI school projects. Finally, conclusions are drawn on the theoretical, managerial and policy implications of the empirical findings. Future research directions are also outlined. 


\section{Literature Review}

\subsection{Sustainable Energy Innovation (SEI)}

Joseph Schumpeter, in his seminal work dating back to 1911, defines innovation as a significant and permanent change (Schumpeter, 1980). Rogers (2003), another important contributor to the study of innovation, described the concept of innovation as a process initiated by the invention of a new technological element, such as an idea, practice, or project, which in turn leads to the development of the element into practical and commercial use. The success of this commercialisation will ultimately result in widespread diffusion and imitation (Rogers, 2003).

Sustainable Energy Innovations (SEIs) are a particular subset of environmental innovations which are broadly defined as "new or modified processes, techniques, practices, systems and products to avoid or reduce environmental harms" (Beise and Rennings, 2005). Classically, innovation with the purpose of promoting sustainable energy often involves two main strategies: energy efficiency and renewable energy. Pursuing energy efficiency in buildings can include approaches such as reducing cooling and heating loads, exploiting passive solar energy and heat sinks for heating, ventilation and cooling, and utilising efficient technologies and control strategies (Ürge-Vorsatz et al., 2007). Increased energy efficiency can lead to the reduction in energy costs as well as whole-life-cycle costs of the building, reduction in $\mathrm{CO}_{2}$ emission levels, and increased comfort, health and wellbeing of the building's occupants (Prindle et al., 2007). Renewable energy, on the other hand, is defined by Sørensen (1991: 386) as 'a flow of energy that is not exhausted by being used' and, thus, renewable energy technologies are a means by which such flows are transformed into usable devices. Renewable energy sources, such as wind, solar, ocean, geothermal, and biomass, are considered to be the 
most efficient and effective solutions to significantly reduce acid precipitation, stratospheric ozone depletion and the greenhouse effect (Dincer, 2000). Taking the definitions of energy efficiency and renewable energy into consideration, the term Sustainable Energy Innovation is used in this study to represent novel technological products or solutions that are successfully integrated into building's design strategies in order to prevent or substantially reduce the negative impacts of energy use by increasing energy efficiency, or utilizing new ways of renewable energy generation.

Conventional innovation management literature has been dominated by a 'linear' perspective of the innovation process. Such models underline the importance of 'technology-push' and 'market-pull' factors for encouraging innovation. The technology-push model of innovation emphasises the significance of a firm's technical capacity, e.g. its physical and knowledge resources, investments in $\mathrm{R} \& \mathrm{D}$ and knowledge management strategies, for its innovative capability (Pellicer et al., 2014). On the other hand, market-pull drivers of environmental innovation may include factors such as competitiveness (e.g. Pujari, 2006) and customer demand for green products (Kammerer, 2009). In the case of environmental innovation, the regulatory framework has also been considered to play an important role (Del Rio Gonzalez, 2009; Porter and van der Linde, 1995). However, several studies in the construction industry have argued that inflexible environmental regulations may discourage innovation by forcing firms to conform to rigid specifications and conventional solutions (e.g. Manseau and Seaden, 2001; Ryghaug and Sørensen, 2009).

While linear models of innovation management have dominated innovation studies and influenced innovation research in the construction industry, recent research studies have recognised another innovation model particularly associated with project-based organisations. 
Complex Product Systems (CoPS) theory predominantly focuses on the relationship between product complexity and the management of innovation. It is based on the premise that as the complexity of a product increases, the dynamics of innovation will largely differ from other types of product, particularly mass-produced relatively simple goods (Hobday, 1998). The Complex System Industry Model was first developed by Miller et al. (1995) in the context of the flight simulation industry. Their model distinguishes between the innovation superstructure of clients/users (airlines), regulators, and professional institutions, and the innovation infrastructure of producers including specialist suppliers and aircraft manufacturers. Managing the interface between the two structures are systems' integrators who provide complete flight simulation systems to airlines for the training of their crews. CoPS are often developed within projects which include systems integrators, buyers, producers/suppliers, users and in some cases governmental agencies and regulators. These 'innovation actors' (Winch, 1998) collaborate in producing CoPS, frequently taking new design decisions and engaging in coengineering throughout the development process (Miller et al., 1995). Winch (1998) maintains that the Complex System Industry Model is largely beneficial to innovation research as it provides a clear illustration of the institutional setting in which firms innovate.

A 'system' perspective to innovation is widely accepted in the construction industry (Blayse and Manley, 2004). Construction innovation is largely seen to incorporate input from a diverse set of participants within a 'product system' (Marceau et al., 1999). Early work by Nam and Tatum (1988) examined the main attributes of the constructed product and strongly argued that the constructed product is a complex product system, and that construction is thus a complex systems industry. Noting the wide range of participants in the construction industry, Marceau et al. (1999) emphasise the need for their close collaboration to achieve innovative outcomes. This is particularly important, given the highly fragmented nature of construction supply 
chains, and the dispersion of knowledge, material, technologies and skills among diverse organisations (Dulaimi et al., 2003).

This study adopts the CoPS model for investigating innovation behaviour in PFI projects- PFI projects exhibit several characteristics of CoPS. They are complex, bespoke, high-cost systems designed to meet the requirements of a specific client (Caldwell et al., 2009). They involve complex long-term interactions among public sector clients/users and private sector producers, spanning multiple decades as the facility is designed, constructed, and used (Howard and Caldwell, 2011). PFI projects often contain complex component interfaces and their development requires the input from multiple skills and knowledge bases (Caldwell et al., 2009). The premise of this study is that SEI on PFI projects cannot be understood as an isolated decision-making process undertaken by one firm. Rather, innovation should be understood as a multidisciplinary activity spanning multiple organisations and circumstances and largely dependent on the collective, dynamic and interactive relationships among multiple project participants.

\subsection{PFI and innovation}

PFI is a specific type of PPP. In a PFI project, a consortium of private sector firms, known as the Project Company (ProjectCo hereafter), assumes the responsibility of designing, building, financing, and operating an infrastructure facility. The ProjectCo, often taking the form of a Special Purpose Vehicle (SPV), is contracted to provide the public services on a long-term concession period (often 25-30 years) with the relevant governmental body (HM Treasury, 2003). In the UK, PFI was introduced in 1992 by the then Conservative government as a means to exert tighter control on public expenditure to curb inflation (Kee and Forrer, 2008). The 
delivery model was seen as a pioneering way of funding public infrastructure by encouraging the private sector to invest in infrastructure projects such as roads, housing, hospitals, and schools. A further motivation was the belief in the capacity of the private sector to achieve improved Value for Money (VfM) and deliver greater efficiency (HM Treasury, 2003).

In PFI projects, the contracting authority awards the project with a single Design Build Finance and Operate (DBFO) contract. The contract allows the ownership of the facility to be transferred to the ProjectCo for the duration of the concession period. In order to bid for the project, the ProjectCo brings together a large number of actors with a wide range of skills to develop the bid and subsequently undertake the project. This is believed to offer the opportunity for ProjectCo actors to simultaneously consider all the tasks involved in the DBFO contract at the beginning of project development (CIC, 2000).

Previous research on PFI highlighted the growing belief that the integrated procurement context under PFI may provide a more supportive environment for collaborative relationships, with the ProjectCo performing the role of the 'System Integrator' (Barlow and Köberle-Gaiser, 2008). ProjectCo integration is seen to accelerate the design process, and stimulate innovation through improved collaboration (Davies and Salter, 2006; Barlow and Köberle-Gaiser, 2008). Davies and Salter (2006) and Robinson and Scott (2008) maintain that the ProjectCo SPV assuming design, construction and operational responsibility for the fixed capital asset is an incentive for the ProjectCo SPV to consider the implication of design and construction decisions on the long-term operational performance of their asset. This is seen to strengthen Design-Construction-Operation communication and collaboration, ultimately supporting innovation efforts (Davies and Salter, 2006; Robinson and Scott, 2008). Figure 1 shows why 
the Over-the-Wall Syndrome in traditional procurement ceases to prevent innovation in PFI projects.

\section{$<$ INSERT FIGURE 1 ABOUT HERE $>$}

However, these espoused innovation benefits of PFI are yet to be supported by empirical evidence. Indeed, a limited number of studies have examined innovation in PFI procurement (Eaton et al., 2006; Barlow and Köberle-Gaiser, 2008; Leiringer, 2006). Eaton et al. (2006) critically evaluated the published PFI literature and developed a theoretical model of the stimulants and impediments to creative behaviour in PFI projects. Using the model to evaluate four PFI projects, they concluded that the significant scope for innovation within PFI projects remains underutilised. Barlow and Köberle-Gaiser (2008) conducted a series of case studies of early PFI hospital projects to examine the effect of PFI procurement on design and construction innovation, particularly innovations that enable greater flexibility to accommodate future changes in healthcare needs. Their findings suggest that PFI has not been supportive of innovation as a result of private sector actors' desire to minimise their risk exposure and the demands placed on public sector actors to reduce cost to meet Value for Money (VfM) assessments. They were also critical of the ability of PFI to encourage more collaborative ways of working and integration between the different project delivery stages. In his study of technological innovation in PPPs, Leiringer (2006) also warns of fully accepting the claimed innovation benefits of the PPP frameworks and calls into question their capacity to force the actors involved to collaborate.

These studies underline the need for greater understanding of the factors shaping the quality of collaboration in PFI projects. Three questions remain unanswered: What are the main elements 
shaping the quality of collaboration in the PFI project environment? How collaborative is the PFI project environment towards the delivery of SEI? Does the collaboration in the pursuit of SEI distinctly differ from efforts to implement other types of innovation? In the next section, we outline the conceptual approach adopted in order to answer our research questions.

\subsection{Conceptual approach}

We have argued in the preceding sections that the CoPS innovation management model is the best-suited theoretical lens for the study of SEI in PFI projects. Particularly, following from this conceptualisation, and in the case of PFI projects, the model distinguishes between the innovation superstructure of public sector clients and users, and the innovation infrastructure of private sector designers, contractors and operators. Managing the interface between the two structures are systems' integrators; the ProjectCo in the case of PFI, who provide serviced facilities to public sector Local Authorities and users. Figure 2 illustrates PFI as a Complex System Model.

\section{$<$ INSERT FIGURE 2 ABOUT HERE $>$}

Collaboration, the focus of our study, is a process where individuals and organisations come together to realise a common goal by building relationships, sharing knowledge, and reaching agreement on mutual benefits (Dietrich et al., 2010). In this paper, following Dietrich et al., (2010: 63), we assess the quality of collaboration in PFI projects in terms of the 'fluency of interactional activities taking place between the collaborative actors'. Two interactional elements are examined upon which the quality of collaboration is assessed: (i) effectiveness of communication and (ii) alignment of objectives. The effectiveness of communication in a 
collaborative setting indicates the ability of collaborative actors to openly and efficiently share knowledge and information and work closely in resolving issues (Dietrich et al., 2010). In addition to communication, alignment of objectives is an equally important element upon which project collaboration quality can be assessed. Rahman and Kumaraswamy (2011) and Ling et al. (2013) underlined the importance of aligning the diverse objectives of the multiple project participants in construction projects. Alignment of objectives indicates the existence of mutual support among participating actors (Ditrich et al., 2010) and facilitates a collaborative environment conducive to SEI in PFI projects. The project-collaboration quality will be examined at three main PFI interfaces, as follows:

\subsubsection{The design/construction/operation interface}

Several studies of CoPS have highlighted the importance of effective multidisciplinary collaboration for successful innovation (Brady et al., 2005; Miller et al., 1995). CoPS projects involve a wide breadth of knowledge and skills and thus innovative non-functional organisational structures are necessary. This is particularly important to co-ordinate production as changing user requirements may require feedback loops from later to earlier stages (Hobday et al., 2000). Indeed, systems integration and effective multidisciplinary collaboration have been highlighted as prerequisites for innovation (Davies and Brady, 2000).

In the construction industry, the importance of effective communication and collaboration for successful innovation has been emphasised in many studies (e.g. Slaughter, 2000; Bresnen and Marshall, 2000; Ben Mahmoud-Jouini, 2000). The need for effective communication and collaboration is particularly vital in the development of sustainable buildings. Intrachooto and 
Horayangkura (2007) underline the importance of close collaboration among designers, engineers and other consultants in order to introduce innovative environmentally-sound technologies into building systems. Rohracher (2001) also argues that different types of services and consultancy become important in the development of sustainable buildings as high levels of expertise are needed to deal with the multifaceted nature of environmental optimisation. Previous studies have particularly highlighted the importance of collaborative relationships among design, construction and operation disciplines (e.g. Dulaimi et al., 2003; Song et al., 2009). The integration of design and construction is often seen to facilitate cost saving and shortened project duration through increased constructability and affordability (Blayse and Manley, 2004; Song et al., 2009), improved environmental performance (Cole, 2000) and innovation (e.g. Eriksson and Westerberg, 2010). Leiringer (2006) also believes that systematic involvement of those responsible for the building's operation as early as possible during the project life cycle can stimulate innovation. This is particularly important for environmental innovations, given the important role operators can play in the energy-efficient management of buildings (Haji-Sapar and Lee, 2005).

\subsubsection{Public sector client-private sector producer interface}

The importance of client-producer collaboration was emphasised by many studies of CoPS (Hobday, 1998; Miller et al., 1995). Early work by Gardiner and Rothwell (1985) identified the role of the client in aircraft and agricultural machinery innovation and went as far as claiming that the client should be a full 'partner' in the design process. To Gardiner and Rothwell (1985) 'tough customers' stimulate superior designs. 
Nam and Tatum (1997) studied the instruments used to stimulate innovation in construction projects. One of the key instruments they reported was client involvement. They have shown that in such a context, clients may play the dominant role of 'champions' to innovative products and processes. Barrett and Stanley (1999) highlight the importance of the briefing process as central to client interaction. They also signal a tendency in the construction industry to view the brief as a 'stand-alone' document produced at the beginning of the project. Once in place, the brief is used by the project team to control any subsequent demands by the client as a way to manage costs and risk. Barrett and Stanley (1999) offer a fresh perspective by emphasising that the 'briefing process should continue throughout the project and the client's requirements should be progressively captured as they emerge' (Barrett and Stanley, 1999 in Ivory, 2004: 497).

In the case of environmental innovation, several studies also underlined the important role of the client in the achievement of sustainable energy objectives and reducing $\mathrm{CO}_{2}$ emissions (Heiskanen and Lovio, 2010; Ornetzeder and Rohracher, 2006). Increased client awareness and environmental responsibility may create a sense of ownership in the design team and reduce financial barriers by legitimising a less rigid budget to support innovation development (Intrachooto and Horayangkura, 2007). Intrachooto and Horayangkura (2007) also maintain that since clients will ultimately finance most of the cost of the innovation, their clear appreciation of the 'value' of the technological development is paramount. 


\subsubsection{Public sector user-private sector producer interface}

Several studies have emphasised the role of users in the innovation process (Hobday, 1998; Gardiner and Rothwell, 1985; Rothwell and Gardiner, 1988). End-users in CoPS projects are often well integrated into the innovation process as products are tailored to fit their requirements and innovation processes are often seen as user-producer driven (Hobday, 1998). The importance of user involvement was also highlighted by other system-oriented approaches to innovation management. Von Hippel's (1988) Distributed Innovation Process Model emphasises the role of users in driving innovation processes, particularly in providing the necessary information about their needs and the context on which the innovation would be used. Edler et al. (2005) highlight the vital role played by users of innovative technologies in requirement identification. The major advantages of users' participation lie not only in developing requirements that are sufficiently clear to be delivered by producers, but also enabling successful application of the procured technology by the users in later stages and determines users' readiness for change (Edler et al., 2005).

In the construction industry context, Slaughter (2000) argues that the complex 'multi-agent' nature of construction projects requires the collaborative efforts of key project actors, including users, to stimulate innovation. For Reich et al. (1996), the high risk and high cost involved in construction projects encourages users' participation in the design process as a means of reducing the risk of failure. Ivory (2004) also pointed out that users in construction projects often interact for a time-limited period with a single product. Contrary to mass-production where users may be involved in a number of iterations of the same product, users for construction products have a limited time to interact. Moreover, the flexibility of the design 
and the ability of users to influence it diminish as the project progresses. Therefore, early involvement of users is critical for their effective contribution to the design process (Ivory, 2004). The need for effective user involvement for the successful implementation of sustainability innovation was also highlighted by studies such as those of Kaatz et al. (2005), Ornetzeder and Rohracher (2006) and Rohracher (2005). User involvement is seen to be mostly important for such innovations, which attempt to develop alternative and radically innovative solutions to realise users' requirements in a more environmentally-friendly manner (Heiskanen and Lovio, 2010).

\subsubsection{Summary}

This section described the conceptual approach adopted where SEI in PFI projects is understood in terms of collaborative relationships among the innovation superstructure of clients and users and the innovation infrastructure of designers, contractors and operators, with the ProjectCo managing the interface between the two structures as Systems Integrator. Indeed, Howard and Caldwell (2011) argue that the management of innovation on PFI projects is particularly problematic as PFI project arrangements involve long-term interactions among public sector users and private sector producers spanning multiple decades as the facility is designed, constructed and used. Therefore, the need for effective inter-organisational collaboration in the development of SEI on the one hand, and the complexity of the PFI project delivery model on the other, lead to increasing interest in the conditions under which SEI will take place. In the next section, the research methodology used to collect the data to examine the study's main issues will be outlined. 


\section{Methodology}

\subsection{The case studies}

Given the exploratory nature of the study, a qualitative case study approach was considered the best-suited for this research (Yin, 2014). The study focused on PFI schools delivered within the context of the UK government's Building Schools for the Future (BSF) programme. BSF was an immensely ambitious programme designed to rebuild or refurbish all secondary schools in England over 15 years at a cost of $£ 45$ billion. As well as being a programme to improve radically the fabric of school buildings and transform the educational experiences of pupils, it had actively sought to embed sustainability (DCSF, 2007). The need for SEI in BSF schools was reinforced by the fact that school buildings are responsible for about $2 \%$ of greenhouse gases emissions in the UK, the equivalent to $15 \%$ of the national public sector emissions (DCSF, 2007). In order to address this challenge, the Department for Children, Schools and Families (DCSF) announced in 2007 that $£ 110$ million would be allocated for sustainable school buildings and set the ambitious target that all new-build schools should be zero-carbon by 2016 (DCSF, 2007) ${ }^{1}$. PFI was the government's preferred project delivery model for 132 new-build BSF schools.

Four new-build BSF PFI school projects were selected for investigation. Three case studies were selected on the grounds that they showed at least one significant SEI (Case studies A, C and D), and one case study was selected on the grounds that it showed no evidence of SEI (Case study B). To control as much as possible for the impact of contextual factors on

\footnotetext{
1 This target was later moved back to 2019 to match the EU Energy Performance of Buildings Directive.
} 
innovation outcomes, the four case studies were early BSF schemes. This is to make sure that the projects were subjected to the same policy and economic environment, and followed the same BSF documentation and national legislation. This was the case with the first three case studies (Case studies A, B and C) which was expected to offer insight into how the BSF PFI project delivery model, as it was during this initial period, influenced the pursuit of SEI. Case

Study D further benefited from the introduction of the government's Carbon Funding and was awarded the extra funding of $£ 50 / \mathrm{m}^{2}$ to meet the operational carbon target of $27 \mathrm{Kg} \mathrm{CO}_{2} / \mathrm{m}^{2} / \mathrm{yr}$. This case study may present a special regulatory context and was included to maximise what could be learned from the study. Table 1 provides a brief outline of the case study projects and the main SEIs implemented.

\section{<INSERT TABLE 1 ABOUT HERE $>$}

\subsection{Data collection}

The unit of analysis in this study is the PFI project and the key project actors involved served as the primary sources of data. Data was collected through semi-structured interviews with ProjectCo, Local Authority and school stakeholders from each case study. This ensured triangulation of the data collected and improved its validity as it allowed the research findings to be based on a convergence of information from multiple sources. Based on the individual composition of each PFI project and a comprehensive discussion with a key Local Authority/ProjectCo informant, the main players in each stakeholder team were identified and selected as key interviewees within each case setting. The number of key informants on each stakeholder team depended on the role of that stakeholder and the number of individuals identified as important contributors by other project members. At least 12 interviews per 
individual PFI construction project were considered adequate to ensure the desired information-richness of the case study (Yin, 2014). In total, 50 interviews were conducted. Table 2 outlines the case study participants. Data collection also involved extensive review of BSF and project-specific documentation.

\section{$<$ INSERT TABLE 2 ABOUT HERE $>$}

A Case Study Interview Protocol was developed to guide the interview process. Three of the case study projects, i.e. Case Studies B, C and D, were under construction when the researcher established first contact with the projects. Case Study A was operational for a few months. Interviewees were asked about their perception of the effectiveness of communication and alignment of objectives with other project participants during the design and construction phases of the project (thus excluding the operation phase). Particularly, the following items were examined:

i. Effectiveness of communication: participant's perception of the extent to which his/her organisation/team has communicated openly, efficiently and sufficiently with the other organisations/teams concerned during the design development process.

ii. Alignment of objectives: Participant's perception of the extent to which his/her organisation/team has worked jointly with the other organisations/teams concerned towards a common SEI goal.

Table 3 outlines the corresponding interview questions. All interviews were recorded and later transcribed. Data collection was carried out over a 13-month period between April 2009 and May 2010. 


\section{$<$ INSERT TABLE 3 ABOUT HERE $>$}

\subsection{Data analysis}

The analysis of the transcribed interviews started by building chronological stories for each case study, triangulating the interpretations from ProjectCo, Local Authority and school respondents. Within-case analysis was then conducted using sensitising codes and tabular displays to cluster and process the data. The within-case analysis helped to develop preliminary understanding of the main issues affecting collaboration for SEI across the interdependent actors. Cross-case comparative analysis was then conducted using tabular displays. This enabled the identification of issues that would hold consistently across the units of analysis. In addition, cross-case analysis was based on literal and theoretical replication. Literal replication in a case study predicts similar results by testing exactly the same principles, conditions and outcomes established by the initial case study. In contrast, a theoretical replication, is a case study that produces different results but for predictable reasons. Literal replication, under the development of a conceptual model, can explain the circumstances under which a particular outcome is likely to take place, whereas a theoretical replication can explain the circumstances when it is not likely to take place (Yin, 2014). In this study we aimed for literal replication between the three innovative cases (Case Studies A, C and D) and theoretical replication in one further case (Case Study B). 


\section{Findings}

This section will present the findings from the four case study projects. The case study findings are divided into three subsections according to the three PFI interfaces outlined in section 2.3. Tables 4, 5 and 6 review the key findings for each PFI interface. The tables summarise emergent issues for each conceptual construct, synthesised from the 50 case study interviews, and demonstrate the theory underlying the empirical findings. The qualitative findings are further illustrated by quotes taken directly from the verbatim transcription of the interviews.

\subsection{Design/construction/operation collaboration}

It has been widely advocated that the integrated procurement context under PFI may provide a more supportive environment for collaborative relationships, with the ProjectCo performing the role of the 'System Integrator' (Barlow and Köberle-Gaiser, 2008; Davies et al., 2009). However, the multiple case study findings indicate that the espoused multidisciplinary collaboration towards SEI, particularly among design, construction and operation disciplines, are often not attainable in PFI projects. Table 4 provides a summary of the main findings.

\section{<INSERT TABLE 4 ABOUT HERE $>$}

In fact, there was an apparent conflict of sustainability objectives among architects and contractors and relationships between the two were challenging across the four case study projects. Conflict of interest often resulted from architects' desire to achieve exceptional results for sustainability and the limited budget available to building contractors. Contractors were seen to settle for meeting the minimum environmental requirements with the least cost. Under 
the D\&B contract, architects felt 'controlled', 'restricted' and driven to 'tokenistic' and 'ecobling' strategies by contractors. The balance of power on PFI contractual structure is in favour of the D\&B contractors and leaves architects in a position where key sustainability decisions are controlled by contractors. This complicates efforts to introduce SEI as it significantly constrains the innovative capacity of architects (Case Studies A-D). The contractor-led D\&B contract also increases the distance between architects and Local Authorities. Across the four case studies, architects were working under building contractors from an early stage and were, therefore, one step removed from the Local Authorities. This restricted the opportunity to build close working relationships as the time spent with the Local Authorities was significantly less than a conventional client. It also complicated the introduction of sustainable solutions into the design process and weakened the ability of the design to develop and mature (Case Studies A, B and C).

In addition, the structure of contractual relationships in the PFI project delivery model was found to weaken Design-Operation collaboration towards SEI. Across the four case studies, Design-Operation communication was restricted by the use of separate D\&B and operational contracts to deliver the PFI project, which increases the distance between design teams and facility managers and disconnects incentives to implement energy-efficient technologies from opportunities to do so. In fact, facility managers across the case study projects were increasingly frustrated with suboptimal design solutions implemented by design teams without consultation with facility managers. The reluctance of the ProjectCo SPV, as the System Integrator, to commit large resources into the bidding stage, due to the risks involved, also meant that facility managers had a limited degree of involvement during the bidding phase and their input post-bidding was restricted to maintenance issues (Case Studies A-D). 
Moreover, Construction-Operation collaboration was weakened by the separation of companies responsible for construction and those responsible for operation (Case Study B). In fact, the case study findings suggest that alignment of sustainable energy objectives among construction and operation disciplines is influenced by two factors; being the ProjectCo composition (Case Studies A, C and D) and the introduction of joint Building ContractorFacility Manager operational energy responsibilities (Case Study D) as will be further explained below.

- First, the innovative projects (Case Studies A, C and D) were delivered by integrated service companies. ProjectCo actors on the three innovative projects unanimously agreed that the ability of their company to deliver integrated services of design, construction, and operation was an incentive for the bid team to strive for the best possible energy solution because ultimately they are responsible for the energy charge. This is opposed to the project where no innovation was implemented (Case Study B) which was delivered by a separated service company. The design and construction of the building was the responsibility of the $\mathrm{D} \& \mathrm{~B}$ contractor, while operation was the responsibility of a Facility Management firm which partnered with the D\&B contractor during the pre-qualification stage. As the building contractor carried no operational risk, they were not incentivised to improve the energy performance of the building beyond the minimum requirements. Innovative energy solutions which were likely to result in increased initial capital cost to the building contractor were, thus, not welcomed.

- Second, the introduction of joint Building Contractor-Facility Manager operational energy responsibilities (Case Study D) encouraged SEI to be implemented. On this project, incentives to improve the operational energy performance of the building were 
supported by the introduction of the operational carbon target of $27 \mathrm{~kg} \mathrm{CO} / 2 \mathrm{~m}^{2} / \mathrm{yr}$ and placing this obligation on the building contractor. As a recipient of the DCSF funding for energy efficiency introduced in 2008, the project was provided with an additional $£ 50 / \mathrm{m}^{2}$ investment to achieve a $60 \%$ reduction in carbon emission based on a baseline of standards set in the Part L 2002 building regulation. This requirement translated into an operational carbon target of no more than $27 \mathrm{~kg} \mathrm{CO} / \mathrm{m}^{2} / \mathrm{yr}$ for core school hours. This operational obligation was placed on the building contractor responsible for designing and building the scheme and aligned their obligation more closely to what has been delivered. As the building contractor was legally liable and financially responsible for any rectification needed for the building to meet this target, they were incentivised to take the operational energy performance of the building into consideration. By introducing specific energy success criteria in joint objectives, both the building contractor and facility manager explicitly declared that these features are significant, which in turn aligned their objectives towards SEI.

To conclude, contradicting established positions on the innovation benefits of ProjectCo integration (HM Treasury, 2003; Davies and Salter, 2006); the research findings indicate that ProjectCo integration on the PFI project delivery model does not necessarily facilitate effective communication among design, construction, and operation disciplines. It certainly does not automatically ensure that the sustainable energy objectives of architects, contractors and facility managers are aligned and that they are working collaboratively towards SEI. 


\subsection{Public sector client-Private sector producers collaboration}

In the PFI project delivery model, engagement processes during the competitive dialogue procedures are specifically designed to allow the ProjectCo and the Local Authority to discuss solutions, develop ideas, and explore options (PfS, 2006). However, the case study findings identify that client-producer collaboration towards SEI is often weak in PFI projects, particularly in relation to the restrictive nature of BSF engagement processes, and the misalignment of their project objectives and priorities. A summary of key findings is provided in Table 5.

$<$ INSERT TABLE 5 ABOUT HERE $>$

Across the multiple case studies (Case studies A-D), the BSF engagement process was seen to be prescriptive and involve many legal and contractual issues, and thus it pushed discussions on the Local Authorities' sustainable energy requirements down the priority list. Communication was difficult because it needed to be equal and uniform across all bidders at tender stage. The competitive nature of the design process also resulted in the ProjectCo SPV reluctance to propose innovative solutions or invest in high-cost energy model whilst bidding due to the risks involved. The limited time allocated to the design process also resulted in poor quality design and the pursuit of the building's aesthetical quality rather than its sustainability. In fact, the competitive nature of the design process inherent in the PFI project delivery model and the limited BSF budget available often meant that a compromise was needed between achieving a contract-winning, aesthetically pleasing design, and a sustainable design. As the ProjectCo bid manager (Case study B) puts it: 


\begin{abstract}
'So, you invest a fair bit in the design to make it a winning design, rather than what's under the skin and can't be seen. As it's a competition, a lot of the people who are looking to score your presentation are looking at the design and the impact of the design and how people will interact with that design, rather than looking at the base data of the energy it is going to use ... By its very nature, the low-energy design dictates that it's not going to have huge areas of glass and big wow factors, it's going to be a conservative design. And in a competition people don't want a conservative design; they want something that's going to shout out!' (ProjectCo bid manager, Case study B).
\end{abstract}

While the case study findings identified that effective dialogue among ProjectCo and Local Authority actors did take place on the innovative projects (Case Studies A, C and D) and was instrumental in clarifying the sustainable energy requirement, this was, however, achieved despite the restrictive BSF process rather than being supported by the process. Indeed, Local Authority BSF management teams on the innovative projects were faced with many challenges, as discussed above, to allow such sustainability discussion to take place. On the three innovative projects (Case Studies A, C and D), ProjectCo actors agreed that the local authorities' clear commitment to sustainability and $\mathrm{CO}_{2}$ reduction in their dialogue with bidders provided the teams with the incentive to pursue innovation for sustainable energy. The high cost and risk involved on PFI bids, the multiple requirements involved, and the low weighting of sustainability on BSF bid evaluation criteria necessitated effective communication between the ProjectCo and the Local Authority to confirm the Local Authority's commitment to the issue. It was this communication that clarified the Local Authority's sustainable energy requirement, provided ProjectCo actors with the confidence that their innovative efforts would be rewarded in bid evaluation, and allowed the requirement to be translated into an innovative sustainable design.

Effective collaboration towards SEI was also reinforced on two of the innovative projects (Case studies $\mathrm{C}$ and D) by what has been referred to in this research as the Local Authority's 'Readiness to Deliver Sustainability'. Supporting arguments in the literature on the need for greater client's competence and understanding of their objectives (Reich et al., 1996; Nam and 
Tatum, 1997), the findings emphasise its importance in sustainable innovation processes. The findings suggest that it was the client's 'Readiness to Deliver Sustainability', in terms of competence, understanding of their sustainability requirements, and determination to pursue a specific sustainable energy objective, one that defines and demands innovation, that was particularly important for SEI (Case Studies C and D). The importance of the Local Authority's ability to engage in debate about sustainability was highlighted by the contractor's education director (Case study D) when he said:

\begin{abstract}
'Every authority that we engage with will talk about sustainability. The interesting thing is that [the Local Authority] meant it and the more the authority drives it and has it spelt out in a document, the better solution they'll get. And it will force bidding organizations to go the extra mile for them. Which is exactly what [the Local Authority] did. Because you could sit and talk to [the Local Authority] and you actually had a high quality debate about sustainability and what they wanted to see and how we could deliver it. And how we could test it. And when it's embedded you can do that. When it's not embedded, it's a bit of lip service' (Contractor education director, Case study D).
\end{abstract}

However, effective client-producer collaboration on two of the innovative projects (Case studies A and C) was interrupted by misalignment of objectives among Local Authority and ProjectCo actors, particularly in relation to the trade-off between the Local Authority's sustainability aspirations and the limited BSF budget allocated. As ProjectCo assistant bid director (Case study C) explains:

\footnotetext{
'I don't think they (referring to Local Authority representatives) ever understand the constraints around a project. We haven't got $£ 50$ million to spend on photovoltaic panels. We've got $\mathrm{X}$ amount of money in total and some of that money can be spent on sustainable solutions. I think sometimes it's bit of a blinkered view of the world from some people in those roles which make it difficult, good people and good intentions and know what they're talking about when it comes to sustainability but sometimes beyond that segment they don't quite grasp the wider context of the project we're working on and which can be really difficult' (ProjectCo assistant bid director, Case study C).
}

While alignment of objectives among project participants is considered one of the essential conditions for implementing innovation (Hobday, 1998; Dulaimi et al., 2003), as the case study findings indicate, this is often not attainable. There remain conflicts of interest within the public 
sector client and private sector producer organisations that restrict the development of collaborative relationships towards SEI.

\subsection{Public sector user-Private sector producers collaboration}

PFI guidance (HM Treasury, 2000) stresses the importance of direct communication between bidders and the ultimate end-users. The BSF engagement process is specifically designed to allow the opportunity for schools to engage with bidders and provide detailed feedback on their developed design proposals (PfS, 2006). However, the case study findings indicate that userproducer collaboration is often not achievable on PFI projects due to the restricted nature of their engagement processes and the misalignment of their sustainability objectives under the PFI contract. Table 6 provides a summary of the main findings.

\section{<INSERT TABLE 6 ABOUT HERE $>$}

First, user-producer communication was restricted by the highly formalised BSF engagement processes, which lacked adequate appreciation of the long-term benefits of engaging with users in expressing their sustainability aspirations and building their awareness. Schools were briefed to be impartial and nonpartisan, and therefore were unable to talk freely with bidders. According to the school head teacher (Case Study D), the school needed to talk in "coded language' throughout the engagement process, which was difficult. As the school head teacher (Case Study D) explains:

\footnotetext{
'Because you'd be sitting in a meeting, they'd be showing you something and I'd be thinking which one had the 'such and such' that I quite liked. But you can't say that. You can't say I don't like it. So it's all, you know. It was madness. Talking in coded language I think the whole time. And I found that very difficult' (School head teacher, Case Study D).
} 
Second, across the four case study projects, joint School-ProjectCo collaboration was found to be weakened by the nature of the PFI contract, which removed the responsibility of the facility's energy performance from schools. As PFI schools, the building is managed by an Operator who oversees all aspects of its performance, including its energy performance. According to one school head teacher (Case Study D), although the merit of this arrangement was that it released school heads from the burden of managing the school premises and allowed them to concentrate on teaching matters, it significantly reduced their control over their building. The school head teacher found that difficult to accept. As the head teacher (Case Study D) explains:

\footnotetext{
'This is the problem with BSF, because although that's my School, I actually don't have a clue as to what's going on up there in those terms at the moment (referring to energy consumption), because it is provided by the facilities management team, which isn't mine. And I find that the hardest thing to be. I don't feel I have control over the School. And I hate it. But I know that they tell you 'That is wonderful because you don't have to worry about it.' But I don't feel that yet. And they say, 'Think of it like being in a hotel room.' Well, I tell you what: if I was in this hotel I'd move out!' (School head teacher, Case Study D).
}

Innovation management theorists, such as von Hippel (1988), maintain that users' incentive to engage in innovative activities rest on their ability to benefit from the results of the innovation. The research findings support this view and offer further explanation to users' incentives to collaborate in sustainable innovation processes. Particularly, the research findings suggest that contractual user-producer relationships may strongly define these espoused innovation benefits. The research findings indicate that contractual practices that remove the responsibility of the facility's energy performance from the user offer limited incentive for the user to consider the operational energy performance of the building as their main concern. In fact, this resulted in sustainability and energy efficiency issues being further down schools' priority list. Schools' priority across the four case studies was fundamentally their educational requirements and achieving transformational learning environments to their pupils. These design aspirations, 
however, often contradicted the energy efficiency objective. Certainly, due to the limited BSF budget, there was a constant effort to balance the school's educational requirement and the sustainable energy requirement. The significance of cost as a barrier to innovation and the need to balance the school's requirement and energy efficiency requirement was highlighted by the assistant bid manager (Case study C) when he said:

\footnotetext{
'Costs, costs, that's the big one, always costs, so spending on energy efficiency versus spending on spacing the school [referring to the design of the school's layout], versus spending on quality of finishing the school, versus spending on landscaping. You're adding money into the pot for that, you're taking money away from somewhere else and it's the balance between getting that right but also providing what the school wants ... ultimately the school needs to be energy-efficient but that's really secondary to delivering the educational requirements of the users. Really it's important but no school Head Teacher is going to tell you that he's really happy that his school is zero carbon but he can't teach because the spaces are rubbish!' (ProjectCo assistant bid manager, Case study C).
}

It follows that, while user-producer collaboration is necessary for CoPS innovation success (Hobday, 1998), the restricted nature of user-producer engagement processes and the misalignment of their sustainable energy objectives under the PFI contract weaken the capacity of such a determinant to support SEI in the PFI project delivery model.

\section{Discussion}

In this section we will discuss the success of PFI in creating a collaborative environment conducive to SEI. We will discuss the quality of collaboration in relation to the two interactional elements examined- effectiveness of communication and alignment of objectives, and subsequently discuss implications for policy, management practice and innovation theory. 


\subsection{Effectiveness of communication}

Effective communication is often seen as a pre-requisite for innovation in CoPS projects (Brady et al., 2005; Miller et al., 1995). Our findings suggest, however, that several characteristics of the ProjectCo internal contractual structure may have introduced barriers to effective communication towards SEI. First, across the case study projects, the use of separated D\&B and operational contracts have increased the distance between designers and operators and separated incentives to implement energy-efficient technologies from opportunities to do so. The contractor-led D\&B contract also restricted the ability of architects to build close working relationships with local authorities and their capacity to establish a shared understanding of the sustainable design solution. In addition, PFI competitive bidding processes were found to strict communication among local authorities, schools and ProjectCo actors. The highly formalised engagement procedures complicated communication and fell short of recognising the longterm benefits of the additional upfront cost and design time needed to establish a clear sustainable energy requirement specific to the client. It also lacked adequate appreciation of the importance of engaging with schools in expressing their sustainability aspirations, building their awareness, and developing their capabilities.

\subsection{Alignment of objectives}

Alignment of objectives among project participants is often seen as a key condition for successful innovation (Hobday, 1998; Dulaimi et al., 2003), however, the case study findings have underlined the diverse and somewhat conflicting sustainability objectives among ProjectCo actors, Local Authorities and schools. Across the four case study projects, architects felt controlled and restricted from pursuing their sustainability aspirations by D\&B contractors. 
Tensions also developed from Local Authorities' desire to achieve exceptional results for sustainability and the limited BSF budget available to building contractors. The limited BSF budget also meant that occasional conflict developed between the schools' transformational learning aspirations and energy-conscious design.

This misalignment of objectives may have been further complicated by several PFI characteristics that restricted the development of collaborative relationships towards SEI. First, ProjectCo contractual structure, particularly the contractor-led D\&B contract confines the innovative capacity of architects as it leaves architects in a position where key sustainability decisions are controlled by contractors. Second, the separation of companies responsible for construction and those responsible for operation, particularly on the project where no innovation was implemented (Case Study B), has meant that the building contractor carried no operational risk, and thus are not incentivised to improve the energy performance of the building beyond the minimum requirements. In addition, the BSF PFI contract removes the responsibility of the facility's energy performance from schools, thus offering limited incentive for schools to consider the operational energy performance of the building as their main concern.

\subsection{Implications for policy and management of innovation}

The empirical findings underline the need for policymakers and project managers to address the main problematic issues identified in order to create a collaborative environment conducive to SEI in PFI projects. It should be noted that the BSF programme was cancelled shortly after the UK coalition government assumed power in May 2010. The programme was criticised for being too bureaucratic, wasteful, and delivering low quality schools. Nevertheless, since its 
initiation in 2004 a total of 123 schools had been completely rebuilt or substantially refurbished under BSF, of which 47 were PFI. A further 85 PFI school projects were unaffected by the cancellation of the programme and plans for their redevelopment continued. In total, PFI was the delivery model for 132 new-build BSF school projects. Interestingly, the subsequent introduction of BSF's successor, the 'Priority Schools Building Programme' by the coalition government in 2012 and their utilization of Private Finance 2 (PF2) contracts, a reformed model of PFI, clearly indicates that private sector involvement through PFI contracts will remain a widely used policy in the procurement of UK school buildings (Semple and Turley, 2013).

Thus, given the centrality of PFI for future government procurement as well as the government's binding commitments under the Kyoto Protocol and its ambitions for zerocarbon schools by 2019, the development of recommendations on how the PFI process should be improved is vital. However, it should be noted that the recommendations made in this section relate specifically to BSF PFI school projects. The recommendations are made based on research findings, which are due to the nature of the chosen research methodology, hypotheses at their current state. The research findings need to be confirmed or rejected by means of quantitative research as representative of all PFI projects.

Based on the identified problematic issues confronted by firms pursuing SEI on BSF PFI projects, the study proposes three potential areas for improvements. First, the findings indicate that the concept of ProjectCo integration deserves further attention, particularly in aligning actors' objectives and priorities towards long-term sustainability in order to ensure that effective integration between design, construction, and operation is successfully achieved. Therefore, to encourage SEI, Local Authorities should formulate bid evaluation criteria that support real integration of the project participants. The ProjectCo, for its part, should also 
ensure that actors with an incentive to develop SEI are provided with the opportunity to do so. For example, adequate resources should be allocated for facility managers' operational knowledge to be utilised in early design development processes. This will not only stimulate innovation, but will ensure that schools designed to be energy-efficient will remain so during operation.

Second, the study identifies three key issues that should be taken into consideration for effective client-producer collaboration towards SEI. First, the nature of the PFI engagement process warrants further attention. Undeniably, the competitive bidding process should be simplified in order to foster collaborative engagement towards SEI. For example, addressing the difficulty of managing the design process under competitive bidding could be achieved through the appointment of design teams separately and as early as possible, thus, allowing more active engagement between designers, Local Authorities and schools. The detailed design could subsequently be handed over to the shortlisted PFI bidders. In addition, the study highlighted the important role played by Local Authority PFI management teams in supporting effective engagement. Therefore, Local Authorities should recruit individuals with the necessary technical and leadership skills when staffing their PFI management team. The study also demonstrates the need for Local Authorities and ProjectCo actors to create a mutual understanding of each other's needs and objectives. The lack of appreciation of affordability among Local Authorities' actors was considered a major barrier for effective collaboration. Therefore, cost/sustainability assessments should be adequately conducted by Local Authorities actors prior to tender.

Third, the limited involvement of schools in developing SEI during PFI engagement processes is a weakness that needs to be addressed. While schools' priority is understandably education, 
their role, as the users of the innovative sustainable building, is vital to the development of successful innovation. Therefore, Local Authorities should ensure that engagement processes are designed to allow sufficient dialogue between schools and bidders. Sustainability and energy issues should also assume a higher profile in schools' requirement identification and discussion with bidders.

\subsection{Implications for innovation theory}

This study makes several noteworthy contributions to the subjects of innovation and collaboration management in PFI projects. The study is the first to adopt the CoPS model to examine the quality of collaboration towards SEI at several key interfaces in the PFI project delivery system. The model was useful in illustrating the institutional context in which firms innovate for sustainability and can serve as a base for future studies on SEI in PFI projects. In addition, examining the quality of collaboration in PFI projects through the lens of CoPS provides a new understanding of sustainability innovation and strongly indicates that the CoPS model should be expanded to account for the dynamics of innovation processes in the procurement of sustainable CoPS. While the alignment of objectives is taken as given in CoPS innovation, however, SEI represents a markedly unique type of innovation with additional challenges, particularly in aligning actors' incentives towards a more sustainable solution. The role of the "System Integrator", in particular, was found to be weak in aligning the multiple sustainability objectives among private sector producers and creating a collaborative environment conducive to SEI. Future research is necessary on the means by which successful alignment could be achieved towards the procurement and delivery of sustainable CoPS. 
Furthermore, the study has gone some way towards enhancing our understanding of the role of the client and users in the procurement of sustainable CoPS. The study has certainly shown that the two entities are distinctly diverse in terms of their sustainability priorities and aspirations. The concept of 'Readiness to Deliver Sustainability' that we have identified may assists in our understanding of the pivotal role of the client and their capabilities in supporting SEI in sustainable CoPS project. The finding also advances von Hippel's (1988) argument on user incentivisation by underlining the importance of contractual user-producer relationships in defining user's incentives to collaborate in sustainable innovation processes. The concept of user incentivisation in sustainable CoPS projects requires further consideration from policymakers and researchers.

\section{Conclusion}

The main aim of this study was to examine the quality of collaboration towards SEI in PFI procurement. Adopting the CoPS innovation management model, SEI in PFI projects was understood in terms of collaborative relationships among the innovation superstructure of clients and users and the innovation infrastructure of designers, contractors and operators, with the ProjectCo managing the interface between the two structures as Systems Integrator. Two interactional elements were examined upon which the quality of collaboration was assessed: (i) effectiveness of communication and (ii) alignment of objectives. The model was applied to four new-build school projects within the context of the UK government Building Schools for the Future (BSF) Programme. Semi-structured interviews with total of 50 key stakeholders were used as the primary data collection method. 
While the qualitative and inductive nature of the chosen research methodology limits the ability to generalise, the research findings provided empirical evidence as to the limited capacity of the PFI project model to support collaborative efforts towards SEI. In fact, the study identified a number of problematic issues weakening collaboration towards SEI in PFI projects. Particularly, the research established that the capacity of the PFI project delivery model to support SEI is weakened by ineffective multidisciplinary communication and collaboration within the integrated ProjectCo due to restricting internal contractual relationships and the misalignment of Design-Construction-Operation sustainability objectives. It is also constrained by ineffective public sector client/user-private sector producer communication and collaboration brought in by the restricted nature of the PFI engagement processes as well as the misalignment of public sector-private sector sustainability objectives.

This identified limited capacity of the PFI delivery model to support collaborative efforts is, however, detrimental to SEI on PFI projects. The nature of sustainability innovation demands increasing levels of functional dependency and components complexity. Thus, project models that do not support the building of collaborative relationships is damaging to SEI development (Rohracher, 2001; Intrachooto and Horayangkura; 2007). Therefore, it is fair to argue that this may represent a considerable challenge to delivering the UK Government's zero-carbon objectives through PFI contracts.

Our study has raised several interesting questions in need of further investigation. First, the findings may suggest that integrated service companies are more incentivised to consider the long-term performance of the building as opposed to separated service companies. The study particularly identified that the integration of companies responsible for construction and those responsible for operation is more conducive to SEI. As the size of the study limits the ability 
to arrive at a conclusive finding, we forward a hypothesis that an integrated service company is more encouraged to implement SEI than a separated service company. Building on the work of Brady et al. (2005) and Davies et al. (2009) on Integrated Solutions Business Models, an important study would be to clarify and further explore this relationship. In addition, the concept of 'Readiness to Deliver Sustainability' was among the key characteristics of innovative Local Authorities identified in our study. The concept is closely related to CoPS Capability Building research (Davies and Brady, 2000) and may warrant further attention from policymakers and researchers. Finally, this study has focused exclusively on two interactional elements- communication and alignment of objectives. Other interactional elements that are conducive to collaborative working, such as trust, cohesion, commitment and conflict resolution (Dietrich et al., 2010) could be examined in school PFI or other types of PFI projects.

\section{References}

Barlow J. and Köberle-Gaiser, M. (2008), Delivering Innovation in Hospital Construction: Contracts and Collaboration in the UK's Private Finance Initiative Hospitals program. California Management Review, 5(2), 1-18.

Beise, M., and Rennings, K. (2005), Lead markets and regulation: a framework for analysing the international diffusion of environmental innovations. Ecological Economics 52, 517

Ben Mahmoud-Jouini, S. (2000), Innovative Supply-based Strategies in the Construction Industry, Construction Management and Economics, 18, 6, pp. 643-650.

Blayse, A. M. and Manley, K. (2004), Key Influences on Construction Innovation. Construction Innovation, 4(3), 143-154. 
Brady, T., Davies, A. and Gann, D. (2005), Can Integrated Solutions Business Models Work in Construction? Building Research and Information, 33(6), 571-579.

Bresnen, M. and Marshall, N. (2000), Partnering in Construction: a Critical Review of Issues, Problems and Dilemmas, Construction Management and Economics, 18, 2, pp. 229-237. Bulkeley, H., Jordan, A., Perkins, R., and Selin, H. (2013), Governing sustainability: Rio+ 20 and the road beyond. Environment and planning c: government and policy, 31(6), 958970.

Caldwell, N., Roehrich, J. and Davies, A. (2009), Procuring Complex Performance in Construction: London Heathrow Terminal 5 and a Private Finance Initiative Hospital. Journal of Purchasing and Supply Management, 15(3), 178-186.

CIC (Construction Industry Council) (2000), The Role of Cost Saving and Innovation in PFI Projects, Construction Industry Council, Thomas Telford, London, UK.

Cole, R. (2000), Building Environmental Assessment Methods: Assessing Construction Practices, Construction Management and Economics, 18, 8, pp. 949-957.

Davies, A. and Brady, T. (2000), Organisational Capabilities and Learning in Complex Product Systems: Towards Repeatable Solutions. Research Policy, 29, 931-953.

Davies, A., Gann, D., and Douglas, T. (2009), Innovation in Megaprojects: Systems Integration at London Heathrow Terminal 5. California Management Review, 51(2), 101-125.

Davies, A. and Salter, A. (2006), The Great Experiment: The Impact of PPP on Innovation in the Procurement and Production of Capital Goods. In: M. McKelvey and M. Holmen (Eds.): Flexibility and Stability in the Innovating Economy, Oxford University Press, Oxford, UK.

DCSF (Department for Children, Schools and Families) (2007), The Children's Plan, The Stationery Office, London, UK. 
De Bruijn, T. and Tukker, A. (2002), Introduction: Collaboration as the New Paradigm in Industrial Transformation, In: T. de Bruijn and A. Tukker (eds.), Partnership and Leadership: Building Alliances for a Sustainable Future, pp. 5-20, Kluwer: Dordrecht. DEFRA (Department for Environment, Food and Rural Affairs) (2007), Draft Climate Change Bill, DEFRA, HM Government, UK.

Del Rio Gonzalez, P. (2009), The empirical analysis of the determinants for environmental technological change: a research agenda. Ecological Economics 68, 861-878.

DETR (Department of Environment Transport and the Regions) (2000), Sustainable Development: What it is and what you can do, DETR Green Ministers Report, March 2000.

Dewick, P. and Miozzo, M. (2004), Networks and Innovation: Sustainable Technologies in Scottish Social Housing. R\&D Management, 34(3), 323-333.

Dietrich, P., Eskerod, P., Dalcher, D., and Sandhawalia, B. (2010), The dynamics of collaboration in multi-partner projects. Project Management Journal, 41(4), 59-78.

Dincer, I. (2000), Renewable Energy and Sustainable Development: A Crucial Review. Renewable and Sustainable Energy Reviews, 4(2), 157-175.

Dorée, A. G. and Holmen, E. (2004), Achieving the Unlikely: Innovating in the Loosely Coupled Construction System, Construction Management and Economics, 22, 8, pp. $827-838$.

DTI (2007), Meeting the Energy Challenge, A White Paper on Energy, Department of Trade and Industry, London, UK.

Dulaimi, M., Ling, F. and Bajracharya, A. (2003), Organizational Motivation and Interorganizational Interaction in Construction Innovation in Singapore. Construction Management and Economics, 21(3), 307-318. 
Eaton, D., Akbiyikli, R. and Dickinson, M. (2006), An Evaluation of the Stimulants and Impediments to Innovation within PFI/PPP Projects, Construction Innovation, 6, 6377.

Edler, J.; Edquist, C.; Georghiou, L.; Rigby, J.; Hafner, S.; Hommen, L.; Papadakou, M.; Rolfstam, M. and Tsipouri, L. (2005), Innovation and Public Procurement: Review of Issues at Stake, Study for the European Commission, European Commission: Brussels.

Egan, J. (1998), Rethinking Construction: The Report of the Construction Task Force, Department of Trade and Industry, London.

Eriksson, P. E. and Westerberg, M. (2010), Effects of Cooperative Procurement Procedures on Construction Project Performance: A conceptual framework. International Journal of Project Management, 29(2), 197-208.

Frantzeskaki, N., Wittmayer, J., and Loorbach, D. (2014), The role of partnerships in 'realising' urban sustainability in Rotterdam's City Ports Area, The Netherlands. Journal of Cleaner Production, 65, 406-417.

Gardiner, P. and Rothwell, R. (1985), Tough Customers: Good Designs. Design Studies, 6, 717.

Haji-Sapar, M. and Lee, S. (2005), Establishment of Energy Management Tools for Facilities Managers in the Tropical Region, Facilities, 23, 9/10, pp. 416-425.

Heiskanen, E., and Lovio, R. (2010), User-Producer interaction in housing energy innovations. Journal of Industrial Ecology, 14(1), 91-102.

HM Treasury (2000), How to achieve design quality in PFI projects, Technote 7, available online: http://www.hm-treasury.gov.uk.

HM Treasury (2003), PFI: Meeting the Investment Challenge, The Stationery Office, London, UK. 
Hobday, M. (1998), Product Complexity, Innovation and Industrial Organization. Research Policy, 26, 689-710.

Hobday, M., Rush, H. and Tidd, J. (2000), Innovation in Complex Products and Systems. Research Policy, 29(7/8), 793-804.

Howard, M. and Caldwell, N. (2011), Procuring Complex Performance: Studies of Innovation in Product-Service Management, Routledge, New York, USA.

Intrachooto, S. and Horayangkura, V. (2007), Energy Efficient Innovation: Overcoming Financial Barriers. Building and Environment, 42, 599-604.

Ivory, C. (2004), Client, User and Architect Interactions in Construction: Implications for Analysing Innovative Outcomes from User-Producer Interactions in Projects, Technology Analysis and Strategic Management, 16, 4, pp. 495- 508.

Kaatz, E.; Root, D. and Bowen, P. (2005), Broadening Project Participation through a Modified Building Sustainability Assessment, Building Research and Information, 33, 5, pp. 441454.

Kammerer, D. (2009), The effects of customer benefit and regulation on environmental product innovation. Empirical evidence from appliance manufacturers in Germany. Ecological Economics 68, 2285-2295.

Kee, J. and Forrer, J. (2008), Private Finance Initiative-The Theory behind the Practice, International Journal of Public Administration, 31, 2, pp. 151-167.

Kelly, K. (2008), Going Green, the Challenges and Solutions, Automotive Design and Production, 120(1), 26-31.

Latham, J. (1994), Constructing the Team, HMSO, London.

Leiringer, R. (2006), Technological Innovation in PPPs: Incentives, Opportunities and Actions, Construction Management and Economics, 24(3), 301-308. 
Ling, F. Y., Ning, Y., Ke, Y., and Kumaraswamy, M. M. (2013), Modelling relational transaction and relationship quality among team members in public projects in Hong Kong. Automation in Construction, 36, 16-24.

Malmborg, F. (2007), Stimulating Learning and Innovation in Networks for Regional Sustainable Development: The Role of Local Authorities, Journal of Cleaner Production 15, pp. 1730-1741.

Manseau, A. and Seaden, G. (2001), Innovation in Construction: An International Review of Public Policies, Taylor and Francis: London.

Marceau, J.; Houghton, J.; Toner, P.; Manley, K; Gerasimou, E. and Cook, N. (1999), Mapping the Building and Construction Product System in Australia, Sydney, Commonwealth Department of Industry, Science and Resources.

Miller, R., Hobday, M., Leroux-Demers, T. and Olleros, X. (1995), Innovation in Complex Systems Industries: The Case of the Flight Simulation Industry. Industrial Corporate Change, 4, 363- 400 .

Nam, C.H. and Tatum, C.B. (1997), Leaders and Champions for Construction Innovation. Construction Management and Economics, 15(4), 259-270.

Nam, C.H. and Tatum, C.B. (1988), Major Characteristics of Constructed Products and Resulting Limitations of Construction Technology, Construction Management and Economics, 6, pp. 133- 48.

Ornetzeder, M. and Rohracher, H. (2006), User-led Innovations and Participation Processes: Lessons from Sustainable Energy Technologies, Energy Policy, 34, 3, pp. 138-150.

Pellicer, E., Yepes, V., Correa, C. L., and Alarcón, L. F. (2014), Model for Systematic Innovation in Construction Companies. Journal of Construction Engineering and Management, 140(4). 
PfS (Partnership for Schools) (2006), The Competitive Dialogue Procedure, available online: http://www.partnershipsforschools.org.uk.

Porter, M. and van der Linde, C. (1995), Towards a New Conceptualization of the Environment-Competitiveness Relationship, Journal of Economic Perspectives, 9, 4, pp. 97-118.

Prindle, B., Eldridge, M., Eckhardt, M. and Frederick, A. (2007), The Twin Pillars of Sustainable Energy: Synergies between Energy Efficiency and Renewable Energy Technology and Policy, American Council for an Energy-Efficient Economy and the American Council on Renewable Energy, ACEEE Report Number E074.

Pujari, D. (2006), Eco-innovation and new product development: understanding the influences on market performance. Technovation, 26 (1) (2006), pp. 76-85.

Rahman, M. M., and Kumaraswamy, M. M. (2011), Multi-country perspectives of relational contracting and integrated project teams. Journal of Construction Engineering and Management, 138(4), 469-480.

Reich, Y., Konda, S., Monarch, I., Sean, N., Levy, S. and Subrahmanian, E. (1996), Varieties and Issues of Participation and Design. Design Studies, 17, 165-180.

Rennings, K. (1998), Towards a Theory and Policy of Eco-Innovation - Neoclassical and Evolutionary Perspectives, ZEW Discussion Paper 98-24, Mannheim: Center for Economic Research (ZEW).

Robinson, H. and Scott, J. (2008), Service Delivery and Performance Monitoring in PFI/PPP Projects. Construction Management and Economics, 27(2), 181-197.

Rogers, E.M. (2003), Diffusion of Innovation, 5th edn, The Free Press, New York

Rohracher, H. (2001), Managing the Technological Transition to Sustainable Construction of Buildings: A Socio-Technical Perspective. Technology Analysis and Strategic Management, 13(1), 137-150. 
Rohracher, H. (2005), From Passive Consumers to Active Participants: The Diverse Roles of Users in Innovation Processes, In: H. Rohracher (ed.) User Involvement in Innovation Processes: Strategies and Limitations from a Socio-Technical Perspective, pp. 9-35, Profil-Verlag: Munich.

Roome, N. (2001), Conceptualizing and Studying the Contribution of Networks in Environmental Management and Sustainable Development, Business Strategy and the Environment, 10, 2, pp. 69-76.

Rothwell, R. and Gardiner, P. (1988), Reinnovation and Robust Designs: Producer and User Benefits, Journal of Marketing Management, 3, 3, pp. 372-387.

Roumboutsos, A. and Saussier, S. (2014), Public-private partnerships and investments in innovation: the influence of the contractual arrangement. Construction Management and Economics, 32(4), 349-361.

Russell, A.D., Tawiah, P. and de Zoysa, S. (2006), Project innovation - a function of procurement mode? Canadian Journal of Civil Engineering, 33(12), 1519-37.

Ryghaug, M. and Sørensen, K. (2009), How Energy Efficiency Fails in the Building Industry, Energy Policy, 37, pp. 984-991.

Schumpeter, J. (1980), Theory of Economic Development, Transaction Publishers: New Jersey. Semple, A., \& Turley, L. (2013), Financing sustainable public-private partnerships.

International Institute for Sustainable Development: Winnipeg, Manitoba, Canada.

Slaughter, E. S. (2000), Implementation of Construction innovation, Building Research and Information, 28, pp. 2-17.

Song, L.; Mohamed, Y. and AbouRizk, S. (2009), Early Contractor Involvement in Design and its Impact on Construction Schedule Performance, Journal of Management in Engineering, 25, 1, pp. 12-20.

Sørensen, B. (1991), Renewable Energy: A Technical Overview. Energy Policy, 19, 386-391. 
Stern, N. (2006) Stern Review on the Economics of Climate Change, HM Treasury, London, UK.

Ürge-Vorsatz, D., Danny Harvey, L. D., Mirasgedis, S., and Levine, M. D. (2007), Mitigating $\mathrm{CO} 2$ emissions from energy use in the world's buildings. Building Research and Information, 35(4), 379-398.

Valkering, P., Beumer, C., de Kraker, J., and Ruelle, C. (2013), An analysis of learning interactions in a cross-border network for sustainable urban neighbourhood development. Journal of Cleaner Production, 49, 85-94.

Von Hippel, E. (1988), The Sources of Innovation, Oxford University Press, New York, USA.

Winch, G. (1998), Zephyrs of Creative Destruction: Understanding the Management of Innovation in Construction. Building Research and Information, 26, 268-279.

Yin, R. (2014), Case Study Research: Design and Methods (5 ${ }^{\text {th }}$ ed.), Sage Publishing, Beverly Hills, CA. 
Figure 1: Traditional vs. PFI procurement and task integration
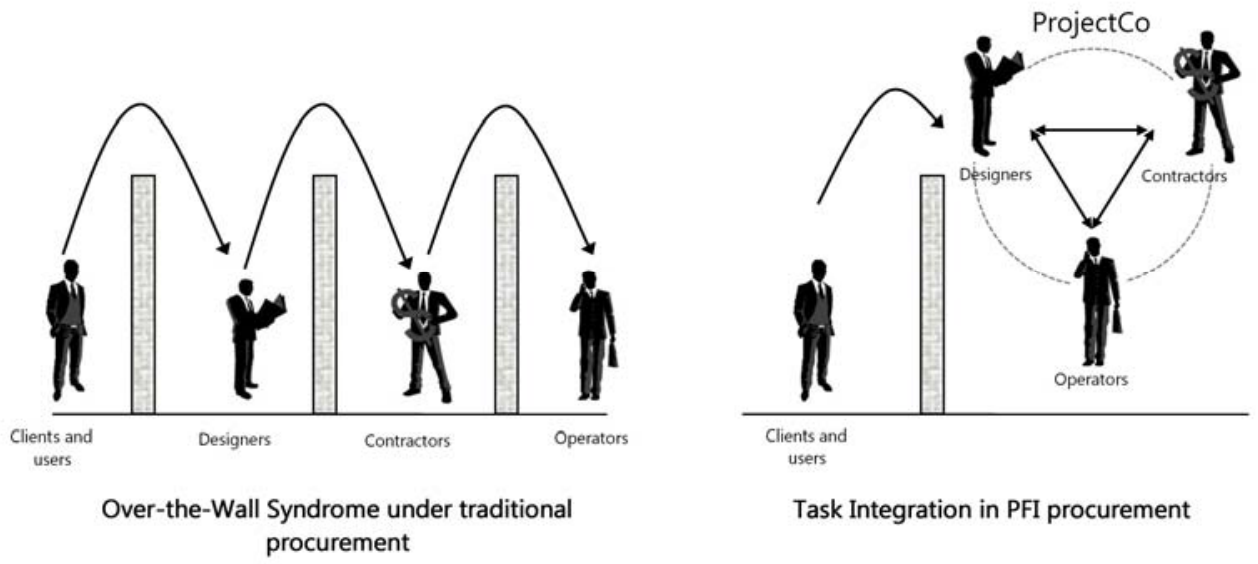

Source: Original 
Figure 2: PFI Complex System Model

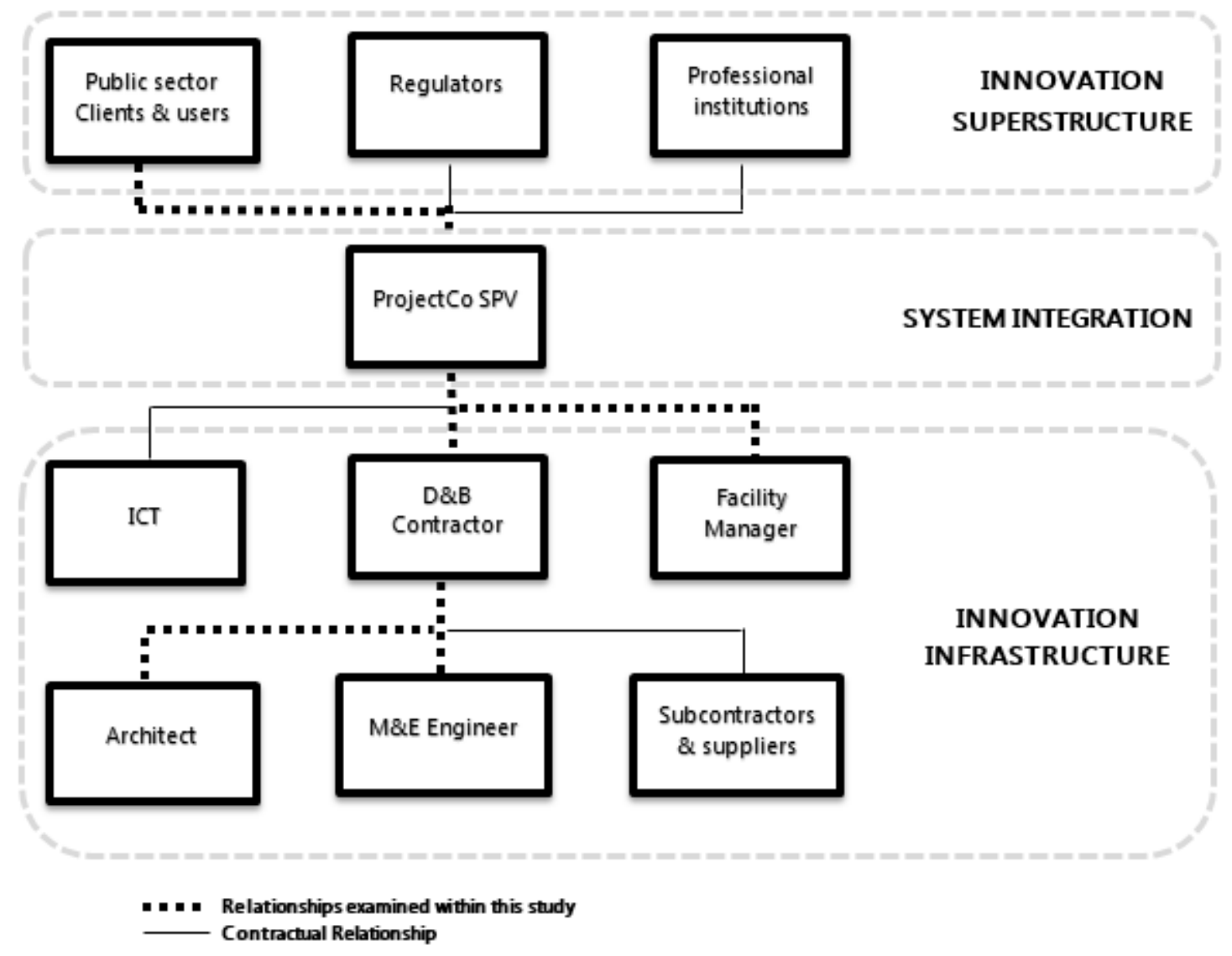

Source: original based on Miller et al. (1995) 
Table 1: The case studies

\begin{tabular}{|c|c|c|c|}
\hline Case Study & Location & Value (£) & Main SEI(s) Implemented \\
\hline A & South West & $\mathrm{f} 34 \mathrm{~m}$ & $\begin{array}{l}\text { The design utilises an innovative ventilation chimney in every } \\
\text { classroom. The innovative chimneys provide outstanding cross air } \\
\text { flow across the classrooms, minimising the need for mechanical } \\
\text { ventilation. The school design achieved } 40 \% \text { reduction in } \mathrm{CO}_{2} \\
\text { emission against Part L } 2002 \text { Building Regulation. }\end{array}$ \\
\hline B & East Midlands & $f 21.5 \mathrm{~m}$ & No SEI was implemented. \\
\hline $\mathbf{C}$ & South East & $\mathrm{f30m}$ & $\begin{array}{l}\text { The design adopts an innovative sustainable energy supply strategy } \\
\text { utilising high-end technologies (mini-Combined Heat and Power } \\
\text { Plant, Ground Source Heat Pump, Earth Tubes, and mini-Wind } \\
\text { Turbine) to offset and reduce carbon emissions and provide micro- } \\
\text { generation. This led to a } 61 \% \text { reduction in } \mathrm{CO}_{2} \text { emissions against Part } \\
\mathrm{L} 2002 \text { Building Regulation and } 25.3 \% \text { reduction against Part L } 2006 \\
\text { Building Regulation. }\end{array}$ \\
\hline D & East Midlands & $\mathrm{f} 20 \mathrm{~m}$ & $\begin{array}{l}\text { The design is based on an innovative energy supply solution with an } \\
\text { Energy Centre housing a biodiesel Combined Heat and Power (CHP) } \\
\text { plant, the first to be implemented in a school in Britain. The CHP } \\
\text { plant provided heating and electricity. It also substantially offset the } \\
\text { demand for grid energy, leading to a dramatic } \mathrm{CO}_{2} \text { reduction of } 60 \% \\
\text { against Part L } 2002 \text { Building Regulation. }\end{array}$ \\
\hline
\end{tabular}


Table 2: Case study participants

\begin{tabular}{|c|c|c|c|c|}
\hline $\begin{array}{l}\text { Team } \\
\text { The local Authority: }\end{array}$ & Case Study A & Case Study B & Case Study C & Case Study D \\
\hline $\begin{array}{l}\text { BSF Management } \\
\text { Team (Core Team) }\end{array}$ & $\begin{array}{l}\text { Project Director } \\
\text { Technical/Design } \\
\text { advisor }\end{array}$ & $\begin{array}{l}\text { Project Manager } \\
\text { In-house Technical } \\
\text { Advisor }\end{array}$ & $\begin{array}{l}\text { Project Manager } \\
\text { Technical Advisor }\end{array}$ & $\begin{array}{l}\text { Design Manager } \\
\text { Technical Advisor } \\
\text { Sustainability Advisor }\end{array}$ \\
\hline Planning Department & Senior Planning Officer & Senior Planning Officer & Senior Planning Officer & $\begin{array}{l}\text { Principal Planning } \\
\text { Officer }\end{array}$ \\
\hline Sustainability Unit & $\begin{array}{l}\text { Sustainability } \\
\text { Coordinator }\end{array}$ & $\begin{array}{l}\text { Sustainability and Low } \\
\text { Carbon Building Officer } \\
\text { Sustainability Manager }\end{array}$ & Head of Sustainability & - \\
\hline $\begin{array}{l}\text { Energy Management } \\
\text { Unit }\end{array}$ & $\begin{array}{l}\text { Energy Management } \\
\text { Officer }\end{array}$ & Senior Energy Officer & Energy Manager & - \\
\hline The ProjectCo: & & & & \\
\hline $\begin{array}{l}\text { Bid Management } \\
\text { Team }\end{array}$ & Bid Manager & Bid Manager & $\begin{array}{l}\text { Assistant Bid Manager } \\
\text { Whole Life Cost Director }\end{array}$ & Bid Director \\
\hline Architect & $\begin{array}{l}\text { Project Director } \\
\text { (Principal Architect) } \\
\text { Project Director } \\
\text { (Development } \\
\text { Architect) }\end{array}$ & $\begin{array}{l}\text { Project Director } 1 \\
\text { Project Director } 2\end{array}$ & Project Director & Project Architect \\
\hline M\&E Engineer & $\begin{array}{l}\text { Project Leader } \\
\text { Project Engineer }\end{array}$ & Project Engineer & Project Engineer & Project Engineer \\
\hline Building Contractor & Design Manager & Operations Manager & Operations Manager & $\begin{array}{l}\text { Operations Manager } \\
\text { Education Director }\end{array}$ \\
\hline Facility Manager & General Manager & Design Co-ordinator & Operations Manager & Contract Manager \\
\hline Energy Consultant & - & - & - & Project Manager \\
\hline The School: & & & & \\
\hline $\begin{array}{l}\text { School BSF } \\
\text { Engagement Team } \\
\text { (SET) }\end{array}$ & School Principal & $\begin{array}{l}\text { School Business } \\
\text { Manager }\end{array}$ & School Head Teacher & School Head Teacher \\
\hline $\begin{array}{l}\text { Number of interviews } \\
\text { per case study }\end{array}$ & 13 & 13 & 12 & 12 \\
\hline $\begin{array}{l}\text { Total number of } \\
\text { interviews }\end{array}$ & \multicolumn{4}{|c|}{50} \\
\hline
\end{tabular}

Source: Developed for this research study 
Table 3: conceptual constructs and corresponding interview questions.

\section{Key Construct(s) Measurement $\quad$ Corresponding Interview Question(s)}

(I) Effectiveness Participant's perception of the extent

of communication to which his/her organisation/team

1 To what extent did your organisation/team communicate openly,

has communicated openly, efficiently

and sufficiently with the other

organisations/teams concerned

during the design development process. efficiently and sufficiently with the following organisations/teams during the design development process?

A. The local Authority:

- BSF Management Team (Core Team)

- Planning Department

- Sustainability Unit

- Energy Management Unit

B. The ProjectCo:

- Bid Management Team

- Architect

- M\&E Engineer

- Building Contractor

- $\quad$ Facility Manager

- Energy Consultant

C. The School:

- School BSF Engagement Team (SET)

(II) Alignment of Participant's perception of the extent

objectives to which his/her organisation/team

has worked jointly with the other

organisations/teams concerned

towards a common SEI goal.
1. To what extent did your organisation/team work jointly with the organisations/teams above towards a common SEI goal?

2. What difficulties did you experience in relating to the above organisations/teams? How did this affect the SEI outcome on the project? 
Table 4: Design-Construction-Operation collaboration and implication for SEI: Summary of key findings

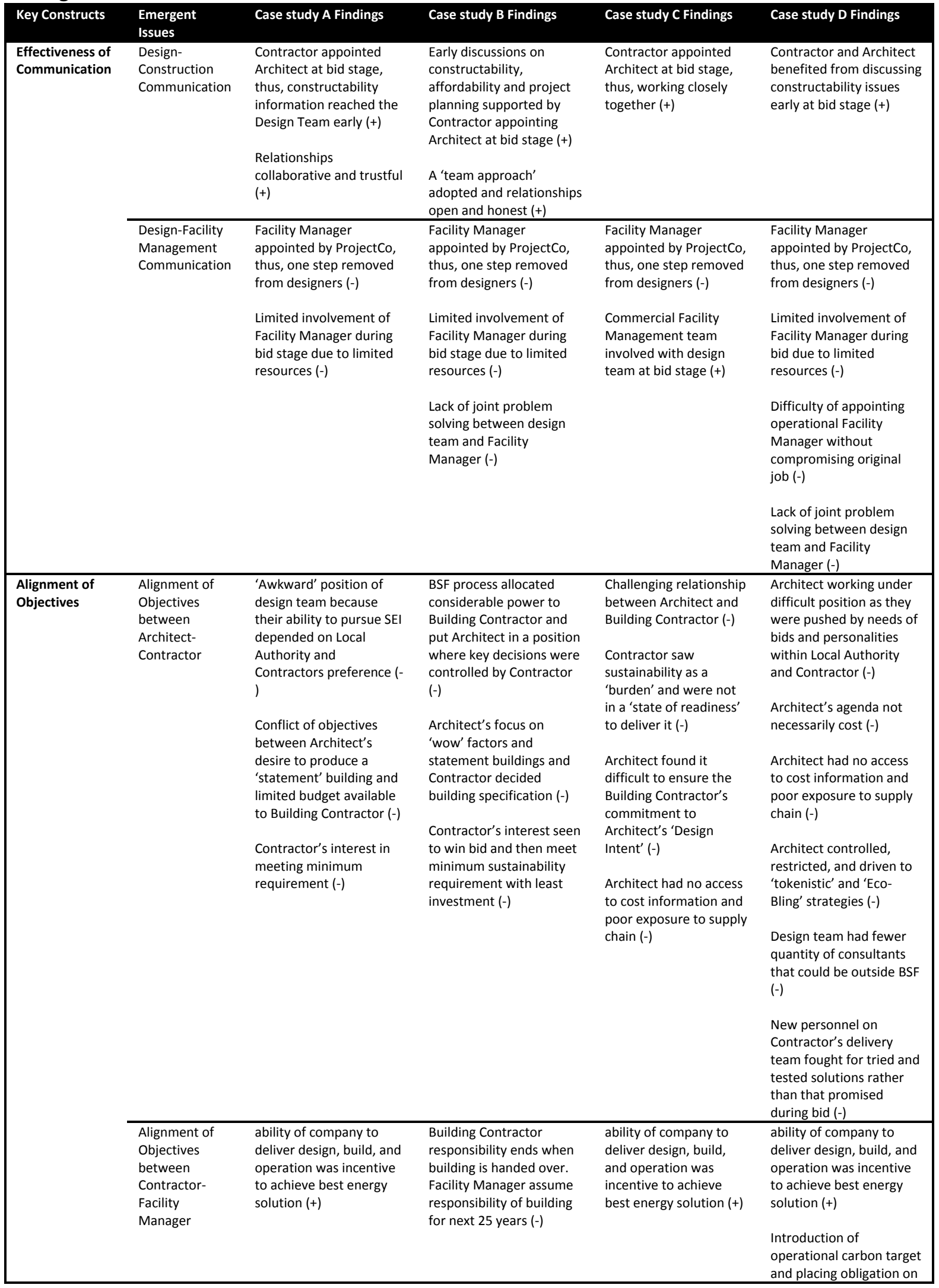


Contractor encouraged

team to design and

operate building

efficiently (+)

Note: (+) indicate that the issue has a positive effect on construct, (-) indicate that the issue has negative effect on construct. 
Table 5: Public sector client-Private sector producers collaboration and implication for SEI: Summary of key findings

\begin{tabular}{|c|c|c|c|c|c|}
\hline Key Constructs & $\begin{array}{l}\text { Emergent } \\
\text { Issues }\end{array}$ & Case study A Findings & Case study B Findings & Case study C Findings & $\begin{array}{l}\text { Case study D } \\
\text { findings }\end{array}$ \\
\hline $\begin{array}{l}\text { Effectiveness of } \\
\text { Communication }\end{array}$ & $\begin{array}{l}\text { Nature of BSF } \\
\text { Engagement } \\
\text { Process }\end{array}$ & $\begin{array}{l}\text { Engagement process } \\
\text { 'difficult, 'restricted' } \\
\text { 'time-consuming' } \\
\text { 'exhausting' and tightly } \\
\text { managed (-) } \\
\text { Large number of } \\
\text { stakeholders } \\
\text { complicated } \\
\text { engagement (-) } \\
\text { Sustainability not high } \\
\text { on the discussion } \\
\text { agenda (-) } \\
\text { confidentiality issues } \\
\text { complicated } \\
\text { communication (-) }\end{array}$ & $\begin{array}{l}\text { Large forums with many } \\
\text { stakeholders involved (- } \\
\text { ) } \\
\text { Communication was } \\
\text { difficulty because it has } \\
\text { to be equal and uniform } \\
\text { across all bidders (-) }\end{array}$ & $\begin{array}{l}\text { Engagement process } \\
\text { 'massively } \\
\text { bureaucratic', } \\
\text { 'cumbersome', 'time- } \\
\text { consuming' and } \\
\text { 'frustrating' (-) } \\
\text { Mammoth amount of } \\
\text { meetings the Local } \\
\text { Authority needed to } \\
\text { attend with all bidders } \\
\text { was exhausting (-) } \\
\text { BSF process } \\
\text { prescriptive and } \\
\text { pushes sustainability } \\
\text { and energy issues } \\
\text { down priority list (-) }\end{array}$ & $\begin{array}{l}\text { Multiple elements } \\
\text { discussed during } \\
\text { engagement meetings } \\
\text { and sustainability not } \\
\text { high on agenda (-) } \\
\text { Magnitude of } \\
\text { stakeholders involved } \\
\text { during engagement } \\
\text { complicated design } \\
\text { process (-) }\end{array}$ \\
\hline & $\begin{array}{l}\text { Local } \\
\text { Authority- } \\
\text { ProjectCo } \\
\text { Interface } \\
\text { Management }\end{array}$ & $\begin{array}{l}\text { Clear information flow } \\
\text { enabled by single points } \\
\text { of contact (+) } \\
\text { Active involvement of } \\
\text { Sustainable City Team } \\
\text { enabled clear } \\
\text { commitment to } \\
\text { sustainability(+) } \\
\text { Lack of understanding } \\
\text { within Core Team of } \\
\text { amount of consultation } \\
\text { needed (-) } \\
\text { Lack of involvement of } \\
\text { Energy Management } \\
\text { Unit (-) }\end{array}$ & $\begin{array}{l}\text { Clear information flow } \\
\text { enabled by single points } \\
\text { of contact (+) } \\
\text { Engagement process } \\
\text { tightly managed by } \\
\text { Local Authority Core } \\
\text { Team (-) } \\
\text { Lack of recognition } \\
\text { within Core Team of } \\
\text { intensity and volume of } \\
\text { work needed to } \\
\text { manage engagement (-) } \\
\text { Lack of involvement of } \\
\text { in-house sustainability } \\
\text { expertise (-) } \\
\text { Depth and quality of } \\
\text { information received by } \\
\text { ProjectCo } \\
\text { unsatisfactory (-) } \\
\text { Local Authority seen } \\
\text { not to understand } \\
\text { sustainability and CO } 2 \\
\text { reduction requirement } \\
\text { (-) } \\
\text { Lack of dialogue to } \\
\text { clarify Local Authority } \\
\text { commitment to } \\
\text { sustainability (-) }\end{array}$ & $\begin{array}{l}\text { Clear information flow } \\
\text { enabled by single } \\
\text { points of contact (+) } \\
\text { Local Authority } \\
\text { requirement made } \\
\text { clear to bidders } \\
\text { through structured } \\
\text { engagement (+) } \\
\text { Sustainability Unit, } \\
\text { Energy Management } \\
\text { Unit and Planning } \\
\text { Department actively } \\
\text { involved, providing } \\
\text { clarity to the Local } \\
\text { Authority's } \\
\text { sustainability } \\
\text { objectives and } \\
\text { aspiration (+) } \\
\text { Sustainability Unit } \\
\text { championing } \\
\text { sustainability across } \\
\text { the Local Authority (+) }\end{array}$ & $\begin{array}{l}\text { Clear information flow } \\
\text { enabled by single } \\
\text { points of contact (+) } \\
\text { Core Team, Design } \\
\text { Manager and } \\
\text { Sustainability Advisor } \\
\text { able to challenge } \\
\text { bidders' proposals, } \\
\text { allowing Local } \\
\text { Authority } \\
\text { Commitment be made } \\
\text { clear to bidders (+) } \\
\text { Design Manger } \\
\text { championing } \\
\text { sustainability across } \\
\text { the Local Authority (+) }\end{array}$ \\
\hline
\end{tabular}

Note: $(+)$ indicate that the issue has a positive effect on construct, $(-)$ indicate that the issue has negative effect on construct. 
Cont. Table 5: Public sector client-Private sector producers collaboration and implication for SEl: Summary of key findings

\begin{tabular}{|c|c|c|c|c|c|}
\hline Key Constructs & $\begin{array}{l}\text { Emergent } \\
\text { Issues }\end{array}$ & $\begin{array}{l}\text { Case study A } \\
\text { Findings }\end{array}$ & Case study B Findings & Case study C Findings & Case study D Findings \\
\hline $\begin{array}{l}\text { Conti. } \\
\text { Effectiveness of } \\
\text { Communication }\end{array}$ & $\begin{array}{l}\text { Architect- } \\
\text { Local } \\
\text { Authority } \\
\text { Relationship }\end{array}$ & $\begin{array}{l}\text { Architect-Local } \\
\text { Authority relationship } \\
\text { was restricted during } \\
\text { engagement (-) }\end{array}$ & $\begin{array}{l}\text { Architect-Local } \\
\text { Authority relationship } \\
\text { was restricted during } \\
\text { engagement (-) }\end{array}$ & $\begin{array}{l}\text { Architect-Local } \\
\text { Authority relationship } \\
\text { was largely } \\
\text { collaborative (+) }\end{array}$ & $\begin{array}{l}\text { Architect-Local } \\
\text { Authority relationship } \\
\text { was restricted during } \\
\text { engagement (-) }\end{array}$ \\
\hline \multirow[t]{2}{*}{$\begin{array}{l}\text { Alignment of } \\
\text { Objectives }\end{array}$} & $\begin{array}{l}\text { Alignment of } \\
\text { Objectives } \\
\text { between Local } \\
\text { Authority and } \\
\text { ProjectCo }\end{array}$ & $\begin{array}{l}\text { Lack of adequate } \\
\text { appreciation of } \\
\text { affordability within } \\
\text { Local Authority (-) } \\
\text { Misalignment of } \\
\text { objectives between } \\
\text { Local Authority and } \\
\text { profit-seeking } \\
\text { Contractors } \\
\text { (-) } \\
\text { No collaboration } \\
\text { between Contractor } \\
\text { and Energy } \\
\text { Management Unit (-) }\end{array}$ & $\begin{array}{l}\text { Lack of appreciation of } \\
\text { affordability within } \\
\text { Local Authority (-) } \\
\text { Local Authority actors } \\
\text { with no power or } \\
\text { influence, with project } \\
\text { dominated by } \\
\text { Contractor (-) } \\
\text { Contractor seen to do } \\
\text { minimum to achieve } \\
\text { required BREEAM } \\
\text { outcome (-) } \\
\text { Contractor inflexible to } \\
\text { Authority's } \\
\text { requirements and } \\
\text { pushing through with } \\
\text { decisions (-) }\end{array}$ & $\begin{array}{l}\text { Tensions in relation to } \\
\text { what Local Authority } \\
\text { wanted to achieve for } \\
\text { sustainability, and BSF } \\
\text { budget allocated (-) } \\
\text { ProjectCo actors felt } \\
\text { engagement with Local } \\
\text { Authority will } \\
\text { complicate design } \\
\text { process and lead to } \\
\text { unrealistic } \\
\text { sustainability demands } \\
(-)\end{array}$ & $\begin{array}{l}\text { Local Authority and } \\
\text { ProjectCo working } \\
\text { collaboratively }(+)\end{array}$ \\
\hline & $\begin{array}{l}\text { Local } \\
\text { Authority } \\
\text { 'Readiness to } \\
\text { Deliver } \\
\text { Sustainability' }\end{array}$ & $\begin{array}{l}\text { Local Authority actors } \\
\text { seen as 'broad concept } \\
\text { people' (-) }\end{array}$ & $\begin{array}{l}\text { Local Authority actors } \\
\text { lacked adequate } \\
\text { understanding of their } \\
\text { requirement (-) }\end{array}$ & $\begin{array}{l}\text { close relationship } \\
\text { between Architect and } \\
\text { Sustainability Unit (+) } \\
\text { Sustainability Unit was } \\
\text { important source of } \\
\text { sustainability } \\
\text { knowledge to Architect } \\
\text { (+) } \\
\text { Local Authority and } \\
\text { Sustainability Unit in a } \\
\text { 'state of readiness' to } \\
\text { push forward a very } \\
\text { sustainable agenda (+) }\end{array}$ & $\begin{array}{l}\text { Local Authority Core } \\
\text { Team receptive, } \\
\text { supportive, } \\
\text { encouraging and willing } \\
\text { to accept new ideas (+) } \\
\text { Local Authority Core } \\
\text { Team clear about their } \\
\text { sustainability } \\
\text { requirements and } \\
\text { determined to pursue a } \\
\text { specific sustainable } \\
\text { energy objective (+) }\end{array}$ \\
\hline
\end{tabular}

Note: $(+)$ indicate that the issue has a positive effect on construct, $(-)$ indicate that the issue has negative effect on construct. 
Table 6: Public sector user-Private sector producers collaboration and implication for SEl: Summary of key findings

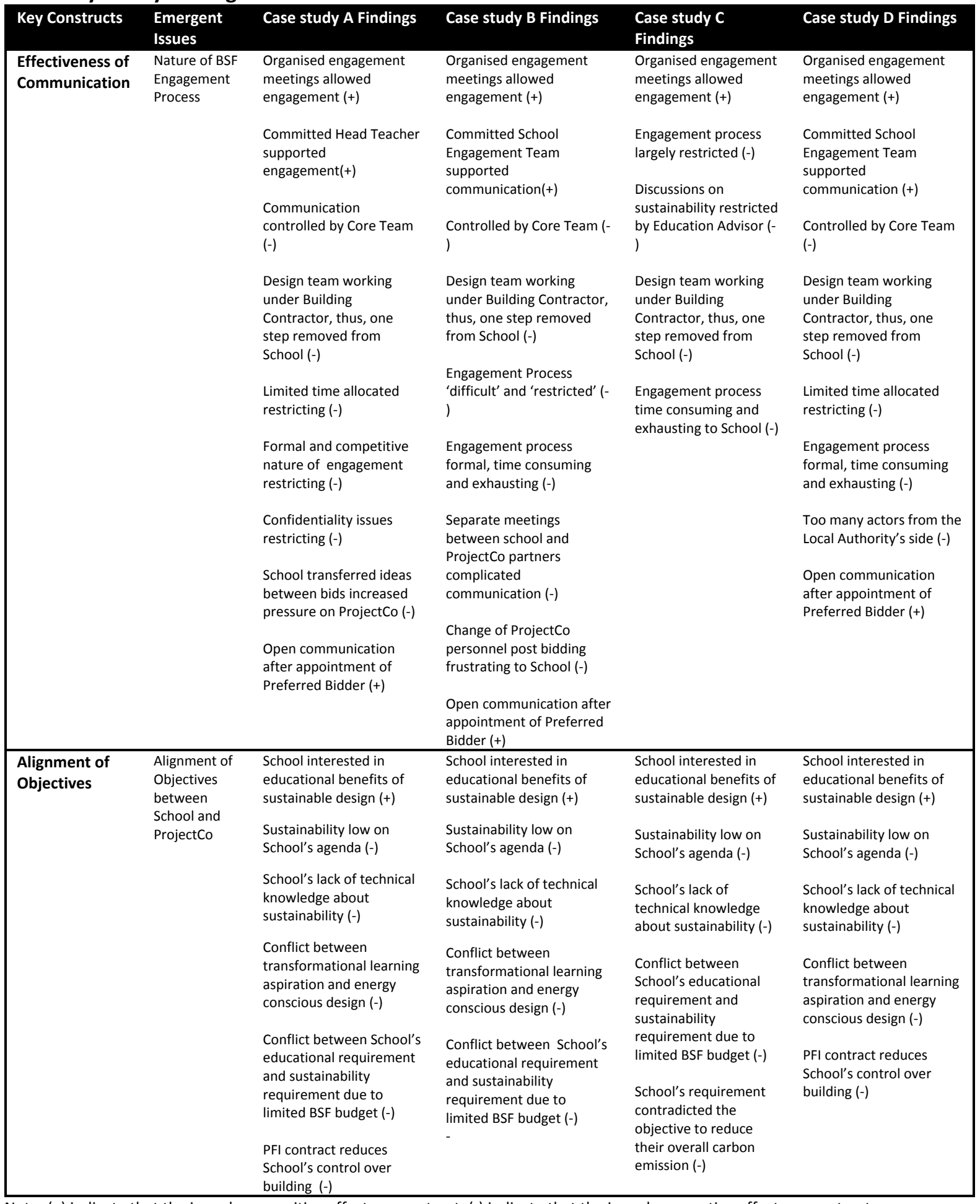

Note: (+) indicate that the issue has a positive effect on construct, (-) indicate that the issue has negative effect on construct. 